\title{
3: 45611355-45696569
}

National Cancer Institute

\section{Source}

National Cancer Institute. 3:45611355-45696569. NCI Thesaurus. Code C45102.

Physical location of LIMD1_Gene 